\title{
An Analysis of Local Wisdom Message through Inheritance Media in the East Java Society
}

\author{
Muslimin M \\ University of Muhammadiyah Malang \\ machmudmus@gmail.com
}

\begin{abstract}
One of efforts in comprehending the phenomenon of inheritance media that have formed and evolved inside a society that is by comprehending the function of inheritance media based on sociocultural interaction. In order to comprehending the phenomenon of local wisdom message in the East Java people, Indonesia, by the implementation of inheritance media, then an appropriate functional theory will be applied. The basic considerations of the functional theory application, because this object of study is related with the society's habit in delivering certain message toward other societies (society culture and local wisdom) that consist of social institution, social relation, social system, and other applicable functions. A functional theory emphasizes on the society situation with the desire to keep the neatness of each component inside the society, also the desire to preserve the neatness by implement a professional work system that consists of conformity and stability through giving a serious attention toward the sociocultural change among the societies, so the functional theory is able to support in analyze the changes. Therefore, theoretically it can be likened that a social change consists of functional matters is able to create stability in the same time (positive function $=$ functional). Otherwise, if the social change interferes the social stability, it is assumed as functional disorder (negative function $=$ dysfunction).
\end{abstract}

Keywords: Functional Analysis, Local Wisdom Message of the East Java Society, Inheritance Media

\section{INTRODUCTION}

Based on history, East Java has many great and influential empires, such as Singosari with its king named Kartanegara, Majapahit with its king named Hayam Wuruk and Patih Gajah Mada, Kahuripan with its king named Erlangga, Kediri with its king named Jayabaya. Therefore, many inheritance media implemented as communucation tool during that era, both among the society or society with the kingdom.

Based on the previous study, it can be further explained the classification and interpretation of the function of inheritance media message that was found in East Java Indonesia, appropriate with the result of interview and observation toward the inheritance media that exist in East Java. The function of inheritance media message can be explained as entertainment and creativity media function, education and spiritual lecture function, promotion and information function, social function, political propaganda function, critical and social control function, also preservation of cultural values function. Inheritance media is an artworks contained in the ritual tradition inside the social culture. Inheritance media and cultural products consist of aura because it is related with ritual and become a unique phenomenon close with magical event inside the society. For the example, wayang kulit, ludruk, ketoprak, or reog in the Javanese society commonly perform all night because it is aimed to attend people in lek-lekan (keep awake all night until morning).

This paper explains some views or comprehension from informant, expert, and other sources toward the function of inheritance media message exist in East Java. Based on the interview, observation by the researcher, and literatures review about the function of inheritance media performance in East Java the following result are obtained:

\section{FUNCTION ENTERTAINMENT AND CREATIVITY}

Entertainment function in the inheritance media performance is one of its roles and purposes that always present during the inheritance media performance, then it can be concluded that entertainment function in the inheritance media performance is a revitalisation of entertainment role within the traditional inheritance media performance. It means that mostly of inheritance media performances consist of entertainment function eventhough there are different ways of delivering. Some of the inheritance media performance try to make a transformation related to the strategy or material in order to modernize it (as an example, kinds of inheritance media performances in East Java make some adjustments in delivering the story or message, as the reason is to fulfill the request from audiences and adjust with the time).

The illustration in accordance with the explanation stated by some figures of Inheritance media in East Java, as explained by Mrs. Endang (owner of inheritance media) who stated that her art group of inheritance media performance always adjust the messages with the 'mass flow', it means that the delivered messages are adjusted with the audience' need. When the audience enjoy a humor or horror story, the actors will play that role. Within the story, messages are inserted about education, information, social control, development, da'wah, and others at once it is able to entertain the audience. Based on that explanation, Mulyana stated that an effective communication when it is as expected by the audiences [9].

\section{FUNCTION EDUCATION AND DA’WAH}

The education and da'wah function of inheritance media are some functions that always provide in every 
performance, they are usualle performed in the form of dialogue, movement, or attribute used by the actors. The messages can be an advice and manners that defined as politeness, value learning, moral education, surrounding, and religion [6]. Related to the education and $d a$ 'wah function of inheritance media, some informants explain that the education and da'wah message in the sense of value learning, moral learning, religious learning, and others are the part of inheritance media performance because of its character as spectacle, order, and guidance.

Mr. Hasan (cultural observer) stated that within the inheritance media performance is full of messages related with kindnesses value, which is called as local wisdom value that deliver in the form of message, both related to human relationship, human and nature relationship, or human and the God relationship. Mrs. Temu also emphasizes that in delivering messages related to invite children to read Al-Qur'an, religion learning, and pray to Allah, are usually delivered through poetry that is related to invitation toward the Muslims in order to comprehend the pillars of Islam and get closer to the God. For example. Invitating for muruk ngaji atau belajar mengaji (learn to read Al-Qur'an). Even, where there is a ceremony invitation, the owner requests to the actors to deliver messages related to persuade children to respect their parents, study and read Al-Qur'an diligently, or other messages that are related to kindnesses value.

\section{Function Promotion and Information}

Some companies are not only promote their products through modern mass media but also by inheritance media and it received positive responses [3]. One of their strategies is the producer toured in some areas and perform about inheritance media. During that show, they present their products and receive a positive response from the audience, because the inheritance media performance becomes a certain entertainment for the audience. It is defined as marketing strategy through local approach. The impact of the inheritance media performance is more perceived through festival program which is an economic impact. It means that where there is an inheritance media performance, many people will gather, then that condition will be used by the merchants in marketing their products. Some small merchants usually sell food and drink while the big merchants will sell electronic stuff, furniture, even vehicle. Therefore, the event is not only to perform about inheritance media but also more than it, even give various effects which at least economic effect.

Mr. Joko Susilo (puppeteer and observer of inheritance media) stated that today inheritance media is also effective for promoting, for some creative companies, modern media is not the only tool in promoting products. There are some conditions where inheritance media is used more effective in promoting products than other media, for instance in persuasion toward traditional society, inheritance media is more effective.

\section{FUNCTION SOCIALIZATION AND POLITICAL PROPAGANDA}

The existence of inheritance media in every area is also utilized by certain people, whether society, non governmental organization, company, or government for socialize an important program or rule toward the society. Some of political party also utilize inheritance media as a political propaganda media in order to attract the people's sympathy. Therefore, when there is a general election in the district, city, province, or central level, inheritance media is used for socialization or campaign about the work program, vision and mission, and who is the legislative candidate. In this condition, inheritance media serve as a propaganda media of the political party. Furthermore, inheritance media is also implemented to campaign, candidate socialization, time and rule of legislation, who is the winner, and other appropriate information related to the voting for the regent, mayor, governor, even president.

As the feedback of the inheritance media implementation for political propaganda is an advantage for certain people while the inheritance media members will get paid for the campaign, such as money, facility, or moral support. An expected result is a positive public opinion about the candidate. Related to the inheritance media as political propaganda, Mr. Katam stated that inheritance media will be targeted by the political candidates during legislation period in order to persuade the society to select them, because this strategy is considered to be more effective.

\section{FUNCTION OF CRITICAL AND SOCIAL CONTROL}

In performing the critical and social control function, inheritance media seems very careful because it creates a dilemma. If the inheritance media strictly implies the critical and social control function, there will be many challenges which have to be faced boldly and wisely (using inteligence, wisdom, reason, and alertness). Facing that condition, inheritance media is confronted with two dilemmatic choices, those are 'die' or break up respectfully as the result of holding critical and principle and idealism (truly imply the critical and social control function) or exits without honor becase of not principled.

The performant's explanation related to the critical and social control function of the inheritance media was definced by Mrs. Endang who stated that sometimes critical statement is delivered through lawakan, because it will be more memorable and related with the society's or government's daily behavior. In criticism, especially toward the government, is implied very carefully for not embarrassing others, because that inheritance media group itself will bear the risk, for instances are not being noticed, unable to accept any facility, even cannot continue the show. 


\section{FUNCTION OF PRESERVATION OF CULTURAL VALUE}

For the preservation cultural value fuction, inheritance media is not only implemented by a society group where the inheritance media was formed, but also implemented by other societies. Information by Mrs. Endang who said that she realized that inheritance media of ketoprak is one of means which is able to preserve the cultural value, especially for East Java culture. She believes that ketoprak is not only watched by Javanese people who stay in East Java but also they who stay outside of East Java. Therefore, as an artist she always implementing preservation effort in order to preserve the art performance of ketoprak by passing it down toward the young generation. While Mr. Ismono stated that inheritance media is able to implement in presenting local culture toward other society, for example is an inheritance media group of orek-orek in Madiun which have been performed in Taman Mini Indonesia Indah, and fully financed by the local governement.

\section{APPLICATION OF FUNCTIONAL THEORY IN THE SOCIETY INHERITANCE MEDIA IN EAST JAVA}

The nature of structural functional theory is the behavior of all the society components, such as group, organization, or culture where all of them act as a system which is exist and related to each other based on their each function. An functional adherent develop a concept about an action system which can be formed as social system, cultural system, personality system, and organizational behavior. In addition to reveal about the functional nature of behavioral system such as adaptation, purpose achievement, integration, dynamism development, social change, and ideas related to exchange media in general. Merton [8] explained some institutional activities in the correlation with the society's need. The intended purpose if it is correlated with media institution, will be associated with the aspect of sustainability, discipline, integration, motivation, direction, or adaptation. Therefore, society is considered as a system that contains of some related parts (read: subsystem), where every part has its own important role.

As explained above that a society is the part of social system consists of some subsystem which is integrated and some mutual support function for the whole society's sustainability and harmony. Such as stated [11], that the functional theory consider the society life is relatively stable harmonious, and balanced. On of the subsystems in the socio-cultural system is communication system, while one of the subsystems in the communication system is inheritance media which have role and function in realizing society's stability and harmony, so it creates a balanced society. Therefore, inheritance media is considered as a local wisdom, tend to be considered as a media in preserving the society's discipline through the performed functions.

\section{CONCLUSION}

If all of inheritance media functions as explained above, they are function of entertainment and creativity, function of educational and da'wah, function of promotion and information, function of socialization and political propaganda, function of criticism and social control, also function of cultural value preservation, are assosiated with the society's reality, then those inheritance media functions will provide benefits to the society. Moreover, the general characteristic of inheritance media fully support those functions. The characteristics are easily accepted, relevant to the local culture, entertaining, use local language, have an legitimacy element, flexible, repeatable message, twoway communication, and others.

\section{REFERENCES}

[1] Adhikarya, R. \& Crawford, R. The Use of Tradisional Media in Family Planning in Rural Java. Ithaca 1979.

[2] Dananjaya, J. Bagaimana Memanfaatkan Media Tradisional Bagi Pembangunan Desa. Jakrta: Grafiti 1972.

[3] Effendy, Onong Uchjana. Ilmu, Teori \& Filsafat Komunikasi. Bandung: PT. Citra Aditya Bakti 1993.

[4] Joko. Pemimpin Agama dan Media Komunikasi Tradisional di Pedesaan. Jogjakarta: Makalah Seminar. LP3ES 1975.

[5] Kumaria, A. Communication and Tradisional Media. Proceedings of a seminar hald at Prune. Dalam Communicator 15 (1980)3, pp 12-17.

[6] Koentjaraningrat. Metode-Metode Kajian Masyarakat. Jakarta: PT. Gramedia Pustaka Utama 1991.

[7] Leckenby, John D \& Everett D. Collier Centennial. The Interaction of Traditional and New Media. Texas: Departement of Advertising College of Communication, The University of Texas at Austin 2003.

[8] McQuail, Denis. Teori Komunikasi Suatu Pengantar Edisi ke 2. Jakarta. Airlangga 1989.

[9] Mulyana, Deddy. Ilmu Komunikasi Suatu Pengantar. Bandung: Remadja Rosdakarya 2007.

[10] Orewere, Ben. Posible Implications of Modern Mass Media for Tradisional Communication in a Nigerian Rural Setting. Africa Media Review Vol. 5 No. 3. Nigeria: African Council for Communication Education 1991.

[11] Ritezer, George \& Douglas J. Goodman. Teori Sosiologi Modern. Diterjemahkan oleh Alimandan. Jakarta: Prenada Media 2004.

[12] Zulyani Hidayah. 1997. Ensiklopedi Suku Bangsa di Indonesia. Jakarta: LP3ES 1997. 